\title{
Differential Accumulation of Potato virus A and Expression of Pathogenesis-Related Genes in Resistant Potato cv. Shepody upon Graft Inoculation
}

\author{
Xianzhou Nie and Rudra P. Singh
}

Agriculture and Agri-Food Canada, Potato Research Centre, P.O. Box 20280, Fredericton, New Brunswick, Canada E3B $4 Z 7$. Accepted for publication 8 November 2000.

\begin{abstract}
Nie, X., and Singh, R. P. 2001. Differential accumulation of Potato virus $A$ and expression of pathogenesis-related genes in resistant potato $\mathrm{cv}$. Shepody upon graft inoculation. Phytopathology 91:197-203.

Potato (Solanum tuberosum L.) cv. Shepody is highly resistant to Potato virus A (PVA), yielding no visible symptoms after rub inoculation. In 'Shepody' rootstocks graft-inoculated by PVA-infected scions from a susceptible host, we found a resistance consisting of traces of necrosis (necrotic streaks) in stems and chlorosis in newly emerged leaves. The response was temperature dependent, appearing at 15 to $18^{\circ} \mathrm{C}$ but not at

reverse transcription polymerase chain reaction and Southern blot procedures. The virus concentration was significantly higher in visibly necrotic areas than in nonnecrotic areas, suggesting that presence of the necrosis may be concentration dependent. Pathogenesis-related gene expression showed that chitinase A and B, glucanase B, and PR-10a were associated with chlorotic or necrotic symptoms in leaves, stems, and tubers. Gene expression was markedly more evident in tuber tissues than in leaves and stems. Furthermore, generation of oxidants was also observed within the necrotic areas. Although PVA was detected in necrotic areas of tubers, newly emerged plants from the same tubers were PVA-free.
\end{abstract} 28 to $31^{\circ} \mathrm{C}$. Necrosis was also observed in tubers, appearing first in the bud end and spreading randomly throughout the majority of the tuber. Trace amounts of PVA in plant tissues were detected by a combination of
Additional keywords: extreme virus resistance, uneven virus distribution.
The largest plant virus family, Potyviridae, includes several viruses that naturally infect the potato (Solanum tuberosum L.), namely Potato virus A (PVA), Potato virus $Y$ (PVY), and Potato virus $V(13,27)$. PVA incites a mild mosaic or no symptoms in potato depending on the cultivars and reduces yield by 10 to $40 \%$ (3). In combination with Potato virus $X$ (PVX), PVA causes a severe disease known as "potato crinkle" (17). The occurrence of PVA in North America is limited to certain cultivars, with incidence rates of 9 to $11 \%(23,32)$. In recent years, the prevalence of PVA in potato production areas of Europe has also been noted (24). Because control of aphid-borne potato viruses like PVA is difficult, the most effective means of preventing virus spread is by using highly resistant potato cultivars.

The hypersensitive response (HR) is an active form of defense that is characterized by the appearance of necrosis at the site of infection and inhibition of further pathogen multiplication and spread (14). Although HR implies restriction of the initial infection, in practice it includes both local and systemic necrotic responses. For example, various tobacco cultivars and Nicotiana spp. containing the $N$ gene express a localized necrosis when plants are rub-inoculated with Tobacco mosaic virus (TMV), but a systemic necrosis when plants are inoculated by grafting (5) or when rub-inoculated plants are maintained for a period of time at a temperature over $28^{\circ} \mathrm{C}$ but below $35^{\circ} \mathrm{C}(8,26)$. Similarly, HR in potato due to viruses has been expressed as the development of necrotic local lesions in inoculated leaves or, alternatively, as the development of systemic necrosis $(4,36)$.

Corresponding author: R. P. Singh; E-mail address: singhr@em.agr.ca

Publication no. P-2000-1218-03R

This article is in the public domain and not copyrightable. It may be freely reprinted with customary crediting of the source. The American Phytopathological Society, 2001.
PVA resistance in potato can be viewed as two distinct phenotypes occurring over time. In the HR, PVA inoculation produces necrotic symptoms, the virus is easily recovered, and the resistance is attributed to $N$ genes $(2,7,13,36)$. With extreme resistance (ER), infection elicits few or no visible symptoms in what is thought to be an intensified localized hypersensitivity (25). From such plants, virus recovery is very difficult, and the resistance is attributed to $R$ genes $(7,20,36)$. Assignment of PVA-resistance types, based on phenotypes to one of the two types (ER and HR), has been difficult in certain cultivars $(2,24,37)$. In such situations it has been speculated that $R$ genes initiate responses that could result in HR, but some $R$ gene responses may prevent disease so effectively that cell death is not activated $(5,12)$.

HR resistance to PVA was originally introgressed from wild Solanum spp. to cultivated potato $(6,7)$, and resulted in a vast majority of progeny of field-immune parents exhibiting HR when inoculated with PVA (38). As a result, approximately $33 \%$ of North American and European cultivars show HR to PVA $(1,34)$. A unique phenotype between ER and HR resistance is encountered in the infection of potato cv. Shepody with PVA, which, in contrast to monogenic inheritance of HR (35), appears to be conferred by two dominant complementary genes (30). No infection takes place in 'Shepody' plants upon rub inoculation, indicating ER resistance, whereas grafted 'Shepody' plants produce chlorotic leaf symptoms with necrotic streaks or spots on stems and tubers, indicating an HR-like response. The virus is not easily detected by enzyme-linked immunosorbent assay or by reverse transcription polymerase chain reaction (RT-PCR) (29). It is, however, detected in low amounts by a combination of RT-PCR and Southern blot (RT-PCR-SB) hybridization (30).

Studies with bacterial, fungal, and viral pathogens have shown that in a classical HR several physiological alterations occur in the plant cell (12,33). Invariably, transcription of pathogenesis-related (PR) genes is induced in neighboring cells (12). The $N$ gene from 
tobacco, which is responsible for $\mathrm{HR}$ against TMV, has been cloned (39). It induces production of both acidic and basic PR proteins in inoculated and systemically infected leaves (16). Rapid generation of oxidants is characteristic of the HR in many plantpathogen systems (15). Such an $N$ gene-mediated oxidative burst has been detected following TMV infection (10). However, these observations are based on systems where phenotypic HR expression is rapid and symptoms develop within days and not weeks.

We examined the delayed HR-like response (weeks versus days after grafting) to PVA in 'Shepody'. We report that PVA-induced necrosis is distributed in discrete locations throughout the PVAgrafted 'Shepody' plants. The degree of necrosis and PVA concentration at these sites are enhanced by low temperature, in contrast to the enhanced accumulation of TMV at elevated temperature in $N$ gene containing tobacco. Furthermore, we show that other characteristics of the HR, i.e., induction of PR gene expression and oxidative burst are also present in necrotic areas of PVA-resistant 'Shepody' plants.

\section{MATERIALS AND METHODS}

Potato virus culture, potato cultivars, and graft inoculation. PVA was a local isolate obtained from a commercial potato field and used in previous studies $(30,32)$. It belongs to strain group four among the categories described by Rajamäki et al. (24). The virus was maintained in PVA-susceptible potato cv. Goldrus in a greenhouse with 12 -h light $\left(90 \mu \mathrm{m} \mathrm{m}^{-2} \mathrm{~s}^{-1}\right)$ at 15 to $18^{\circ} \mathrm{C}$ to optimize virus symptoms (28). Virus-free potato cv. Shepody plantlets were obtained from the Plant Propagation Centre (New Brunswick Department of Agriculture and Rural Development, Fredericton, Canada). The plantlets were transplanted in $12.5-\mathrm{cm}$ pots and maintained in a greenhouse. Prior to PVA graft inoculation, the plantlets were routinely confirmed to be PVA-free by RT-PCR-SB $(30,31)$. When 'Shepody' plantlets (rootstocks) were approximately 6-weeks old, they were cleft-grafted with shoots of PVAinfected potato plants of cv. Goldrus (scions). Visual observations were made and virus detection was carried out in scions and rootstocks at 30-, 40-, and 90-days postgrafting (dpg) by RT-PCR-SB (30). Five control plants were grafted with healthy 'Goldrus' shoots. At $90 \mathrm{dpg}$, tubers were harvested and stored at 20 to $25^{\circ} \mathrm{C}$. After approximately 3 months of storage, when sprouts began emerging, tubers were planted in the greenhouse to study the presence of virus in the second generation. Graft inoculation and symptom observation of 'Shepody' plants were carried out at two temperatures $\left(15\right.$ to $18^{\circ} \mathrm{C}$ and 28 to $31^{\circ} \mathrm{C}$ ) in adjacent rooms of a greenhouse. In each experiment, 15 to 20 plants were grafted, and the experiment was repeated using growth rooms at 15 to $28^{\circ} \mathrm{C}$.

Nucleic acid extraction. For virus detection only, RNA was isolated from different tissues as previously described $(30,31)$. The RNA was quantified by measuring the absorbency at $260 \mathrm{~nm}$ $\left(A_{260}\right)$. For mRNA as well as virus detection, RNA was isolated according to Mohapatra et al. (19). Five grams of leaf, stem, or tuber tissue was ground in liquid $\mathrm{N}_{2}$ with a pestle and mortar, incubated with $10 \mathrm{ml}$ of preheated $\left(60^{\circ} \mathrm{C}\right)$ extraction buffer $(0.2 \mathrm{M}$ sodium acetate, $10 \mathrm{mM}$ EDTA, $0.2 \%$ sodium dodecyl sulfate [SDS], and $0.1 \mathrm{M} \beta$-mercaptoethanol at $\mathrm{pH} 5.2$ ), and $10 \mathrm{ml}$ of water-saturated phenol. After centrifugation at $6,000 \times g$ at $4^{\circ} \mathrm{C}$ for $15 \mathrm{~min}$, the aqueous phase was extracted with 1 vol of phe$\mathrm{nol} / \mathrm{chloroform} /$ isoamyl alcohol $(25: 24: 1, \mathrm{vol} / \mathrm{vol} / \mathrm{vol})$, followed by 1 vol of chloroform (chloroform/isoamyl alcohol, 24:1, $\mathrm{vol} / \mathrm{vol}$ ). Nucleic acids were precipitated by incubation in $2 \mathrm{M}$ $\mathrm{LiCl}$ at $4^{\circ} \mathrm{C}$ overnight and collected by centrifugation at $10,000 \times g$ at $4^{\circ} \mathrm{C}$ for $30 \mathrm{~min}$. The pellet was air dried, dissolved in $400 \mu \mathrm{l}$ of distilled sterile $\mathrm{H}_{2} \mathrm{O}$, treated with RNase-free DNase I at $37^{\circ} \mathrm{C}$ for $10 \mathrm{~min}$, and extracted with phenol (1 vol) once, then phenol/ chloroform/isoamyl alcohol (25:24:1), and finally chloroform/ isoamyl alcohol (24:1). The aqueous phase was collected and RNA was precipitated with $2 \mathrm{vol}$ of ethanol in the presence of $0.1 \mathrm{vol}$ of $3 \mathrm{M}$ sodium acetate $(\mathrm{pH} 5.2)$ overnight at $-20^{\circ} \mathrm{C}$. The RNA was collected after centrifugation at $12,000 \times g$, dissolved in $100 \mu \mathrm{l}$ of distilled sterile $\mathrm{H}_{2} \mathrm{O}$, and quantified spectrophotometrically.

RT-PCR. For PVA analysis, PVA antisense primer (Table 1) was used for RT. The RT was performed as described previously (31) with the following modifications. Briefly, $50 \mathrm{ng}$ of total RNA was denatured at $65^{\circ} \mathrm{C}$ for $5 \mathrm{~min}$ and chilled on ice and combined with the RT mixture to a final volume of $10 \mu \mathrm{l}$. The RT reaction contained $50 \mathrm{mM}$ Tris- $\mathrm{HCl}, 75 \mathrm{mM} \mathrm{KCl}, 3 \mathrm{mM} \mathrm{MgCl} 2,1.5 \mu \mathrm{l}$ of phosphate-buffered saline, $0.1 \mathrm{M}$ dithiothreitol (Gibco BRL, Life Technologies, Gaithersburg, MD), $0.5 \mathrm{mM}$ each of dNTPs (Promega Corp., Madison, WI), $0.1 \mu \mathrm{g} / \mu \mathrm{l}$ of PVA antisense primer, 20 units of RNasin (Promega), and 200 units of cloned Moloney murine leukemia virus RT (Gibco BRL). The reaction mix was incubated at $42^{\circ} \mathrm{C}$ for $1 \mathrm{~h}$, and the reaction was terminated by heating to $95^{\circ} \mathrm{C}$ for $2 \mathrm{~min}$.

For mRNA and viral RNA analysis together, RT was carried out using oligo $(\mathrm{dT})_{21}$ as antisense primer as described (21). One microgram of total RNA in $5 \mu \mathrm{l}$ was mixed with $1 \mu \mathrm{l}(1 \mu \mathrm{g})$ of $(\mathrm{dT})_{21}$. The mixture was incubated at $65^{\circ} \mathrm{C}$ for $5 \mathrm{~min}$, chilled on ice for $3 \mathrm{~min}$, and added to $14 \mu \mathrm{l}$ of the RT mixture, as described previously. After RT was terminated, $80 \mu$ of sterile $\mathrm{H}_{2} \mathrm{O}$ was added to make a final volume of $100 \mu \mathrm{l}$. Four microliters of the cDNA solution was added to $21 \mu \mathrm{l}$ of PCR mixture for amplification.

PCR was carried out by both sense and antisense primers for PVA or PR genes (Table 1). PCR was performed in a volume of $25 \mu \mathrm{l}$ containing $4-\mu \mathrm{l}$ aliquots of the cDNA mixture, $10 \mathrm{mM}$ Tris$\mathrm{HCl}$ at $\mathrm{pH} 8.3,50 \mathrm{mM} \mathrm{KCl}, 1.5 \mathrm{mM} \mathrm{MgCl}_{2}, 100 \mu \mathrm{M}$ each of dATP, dCTP, dGTP, and dTTP (Promega), $0.1 \mu \mathrm{g}$ each of the sense and antisense primers, and 0.625 units of Taq polymerase (PerkinElmer Applied Biosystems, Foster City, CA). Samples were amplified in 15 to 30 cycles (Peltier Thermal Cycler, PTC-200; MJ Research, Watertown, MA) with denaturation at $94^{\circ} \mathrm{C}$, primer annealing at 55 or $60^{\circ} \mathrm{C}$ and primer extension at $72^{\circ} \mathrm{C}$, each for

TABLE 1. The primer pairs specific for Potato virus A and several host messenger-RNAs used in reverse transcription-polymerase chain reaction

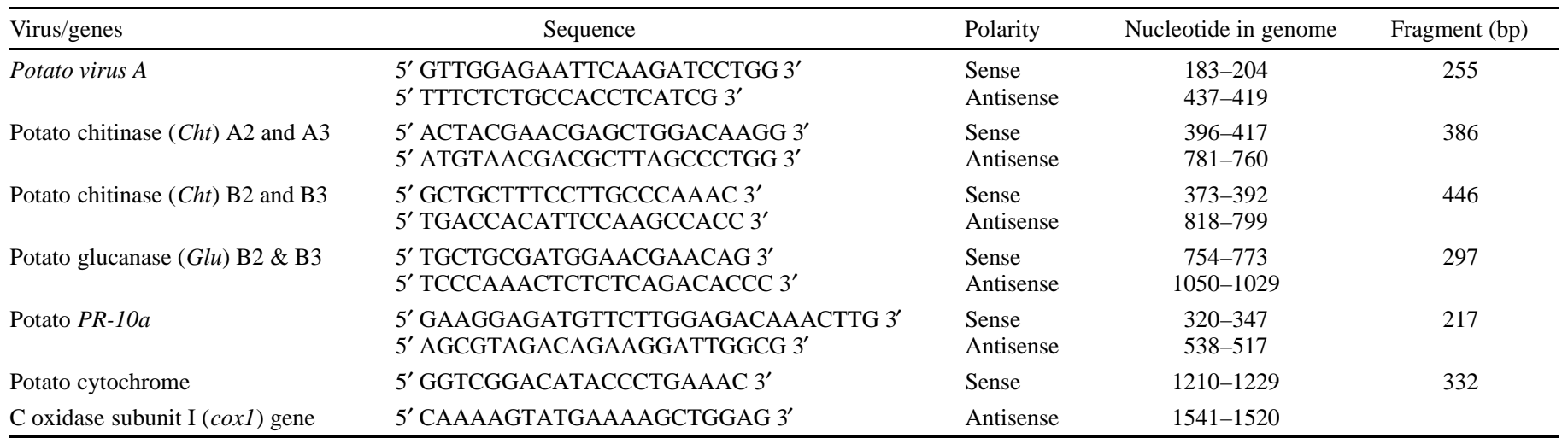


$1 \mathrm{~min}$. A total of $10 \mu \mathrm{l}$ of the amplification product was fractionated by electrophoresis on a $1.5 \%$ agarose gel containing $0.5 \mu \mathrm{g} / \mathrm{ml}$ of ethidium bromide and photographed under UV illumination. A low mass DNA ladder (Gibco-BRL) was used in the gel to determine the size of the amplified products. After the electrophoresis, the gel was blotted to Hybond $\mathrm{N}+$ (Amersham Pharmacia Biotech, Uppsala, Sweden) according to the manufacturer's instructions.

Southern blotting. The blotted membrane was rinsed briefly in $2 \times \mathrm{SSC}(1 \times \mathrm{SSC}$ is $0.15 \mathrm{M} \mathrm{NaCl}$ plus $0.015 \mathrm{M}$ sodium citrate, $\mathrm{pH}$ 7.0) and air-dried. The DNA was fixed by UV cross-linking under UV illumination for 1 to $2 \mathrm{~min}$. The membrane was prehybridized in a solution containing $5 \times \mathrm{SSC}, 50 \%$ formamide, $0.1 \%$ sodium-lauryl sarcosine, $0.02 \% \mathrm{SDS}$, and $2 \%$ blocking reagent (Boehringer $\mathrm{GmbH}$, Mannheim, Germany) at $42^{\circ} \mathrm{C}$ for $1.5 \mathrm{~h}$. The solution was replaced with fresh prehybridization solution plus denatured digoxigenin (DIG)-labeled probe and incubated at $42^{\circ} \mathrm{C}$ overnight. After hybridization, the filter was washed twice with $2 \times \mathrm{SSC}$ plus $0.5 \% \mathrm{SDS}$ at $65^{\circ} \mathrm{C}$, and twice with $0.5 \times \mathrm{SSC}$ plus $0.1 \% \mathrm{SDS}$ at $65^{\circ} \mathrm{C}$, for $15 \mathrm{~min}$ each time. The filter was incubated with anti-DIG alkaline phosphatase (AP), followed by incubation with chemiluminescent substrate disodium3-(4-methoxyspriro $\{1$, 2-dioxetane-3,2'-(5'-chloro)tricyclo[3.3.1.1.7. $]$ decan $\}-4-y l)$ phenyl phosphate according to the manufacturer's instructions $(\mathrm{GmbH})$. The chemiluminescent signals were detected by exposure to X-ray film (X-AR; Kodak, Rochester, NY) at room temperature.

For quantitative analysis of PVA RNA in sample tissues, a concentration series ranging from 0 to 2 ng of purified PVA RNA was used as a standard for RT-PCR-SB, as previously described. The resulting bands were quantified using the EagleSight software (version 3.2, Stratagene Inc., La Jolla, CA). The concentration of PVA RNA from different samples was determined by comparison with the purified PVA RNA standards.

Preparation of probes for PVA and PR genes. DIG-labeled probes were prepared using PCR-amplified fragments produced in the presence of DIG-dUTP $(\mathrm{GmbH})$. For PVA, purified viral RNA was used as template. For cytochrome c oxidase subunit I (coxl), total RNA from potato leaf was extracted according to Mohapatra et al. (19) and used as template for RT-PCR. The 255-bp fragment of PVA and 332-bp fragment of coxl were excised from the gel, purified by phenol/chloroform extraction, and used as a template for DIG labeling by PCR, according to the manufacturer's instructions $(\mathrm{GmbH})$. However, for chitinase A and B, glucanase B, and PR-10a, the cloned portions of these genes were used directly as templates for DIG labeling of their corresponding probes.

The probes were precipitated by $2 \mathrm{vol}$ of ethanol in the presence of $0.1 \mathrm{vol}$ of $8 \mathrm{M} \mathrm{LiCl}$ at $-20^{\circ} \mathrm{C}$ overnight, pelleted by centrifugation at $13,000 \times g$ for $30 \mathrm{~min}$, and dissolved in $200 \mu \mathrm{l}$ of TrisEDTA buffer ( $\mathrm{pH}$ 8.0). Probe quality was checked by electrophoresis in $1.5 \%$ agarose. Addition of the DIG label to the PVA fragment was demonstrated by its reduced migration rate.

Lipid peroxidation assay. Lipid peroxidation was determined by the thiobarbituric acid (TBA) method, according to May et al. (18). Five hundred milligrams of tissue was ground in $1 \mathrm{ml}$ of distilled water. To the 500- $\mu$ l homogenate were added $125 \mu \mathrm{l}$ of $3 \%$ SDS (wt/vol), $250 \mu \mathrm{l}$ of $3 \%$ TBA in $50 \mathrm{nM} \mathrm{NaOH}$, and $250 \mu \mathrm{l}$ of $25 \% \mathrm{HCl}$ ( $\mathrm{vol} / \mathrm{vol})$, with thorough mixing after each addition. The mixture was heated at $80^{\circ} \mathrm{C}$ in a water bath for $20 \mathrm{~min}$ and snap-cooled on ice. TBA-reactive species (TBARs) were extracted with $1.5 \mathrm{ml}$ of butanol. The low nonspecific $A_{600}$ values were subtracted from the high specific $A_{532}$ values of the organic phase, and the measurements were expressed as $A_{532} \mathrm{~g}^{-1}$ fresh weight.

\section{RESULTS}

Infection and reaction of 'Shepody' plants by PVA at two temperatures. During the summer months in greenhouse, when temperature $\left(28\right.$ to $\left.31^{\circ} \mathrm{C}\right)$ and light intensity $\left(135 \mu \mathrm{m} \mathrm{m}^{-2} \mathrm{~s}^{-1}\right)$ were high, 20 rootstocks of 'Shepody' plantlets grafted with PVA-containing scions failed to develop chlorotic spots in leaves and necrotic streaks in stems or produce high levels of PVA as analyzed by RT-PCR-SB. Forty-seven tubers produced by these plants did not show necrotic symptoms nor was PVA detected in any plant subsequently grown from these tubers. PVA-infected scions from 'Goldrus' from the same grafted plants, tested at 30, 40, and $90 \mathrm{dpg}$ contained a high level of PVA throughout the testing period (Fig. 1 , lanes 30 to 33 ). Twenty 'Shepody' rootstocks, grafted during October to December at low temperatures $\left(15\right.$ to $\left.18^{\circ} \mathrm{C}\right)$ and light intensity $\left(60 \mu \mathrm{m} \mathrm{m}^{-2} \mathrm{~s}^{-1}\right)$, developed chlorotic and necrotic symptoms and PVA was detected in leaf, stem, and tuber tissues. Of the 45 tubers produced, 15 showed various amounts of necrosis. However, none of these tubers produced PVA-containing plants when planted. Greenhouse observations on symptom expression and virus concentration were confirmed when experiments were repeated using growth rooms at 15 and $28^{\circ} \mathrm{C}$ (data not shown).

At 15 to $18^{\circ} \mathrm{C}$, tiny isolated necrotic streaks first occurred in the stems close to the graft union on the rootstock approximately 2 to 3 weeks after grafting. With time, the necrotic streaks increased in size and number. Chlorotic spots appeared in some newly emerged leaves 3 to 4 weeks after grafting. However, as these leaves enlarged, chlorotic areas became fainter and eventually disappeared. Concurrently, chlorotic spots continued to appear in other newly emerged leaves. Necrotic streaks in the stems occurred mainly at the nodes and only occasionally in the internodes. At later developmental stages, some necrotic streaks were as long as $2 \mathrm{~cm}$. Necrotic symptoms also appeared on the stolons but not on the roots. Necrosis in tubers appeared in the bud end first, and later spread randomly throughout the tuber. The necrotic symptoms continued internally, and the tuber tissues became hard and dry (30). Only one-third of the tubers produced by a grafted plant developed necrotic symptoms.

RT-PCR-SB analysis revealed that in graft-inoculated 'Shepody' plants more PVA accumulated in plants maintained at 15 to $18^{\circ} \mathrm{C}$ (Fig. 1, lanes 11 to 20 ) than at 28 to $31^{\circ} \mathrm{C}$ (Fig. 1, lanes 1 to 10 ). However, for susceptible cv. Goldrus, the virus accumulation was unaffected by temperature (Fig. 1, lanes 26 to 29 and 30 to 33).

Association of chlorotic spots in graft-inoculated 'Shepody' leaves with the presence of PVA. A previous study (30) indicated that significantly lower amounts of PVA were present in graftinoculated 'Shepody' leaves compared with leaves in susceptible cv. Goldrus. In order to understand the resistance of 'Shepody' plants to PVA, we isolated RNA separately from the chlorotic spots and surrounding green areas of leaves showing typical chlorotic mosaic in PVA-grafted 'Shepody' plants. RT-PCR was carried out to amplify PVA RNA in the extracts. RNA from isolated chlorotic spots produced a barely discernible PVAspecific band (255 bp) (Fig. 2A, lanes 3 to 6). No such bands were produced by the extract prepared from the whole leaf showing chlorotic mosaic symptoms (Fig. 2A, lanes 1 to 2) or the isolated green regions (Fig. 2A, lanes 7 to 10) of a chlorotic mosaic leaf. Southern blot analysis of the same preparations showed strong virus-specific bands in samples from chlorotic spots (Fig. 2B, lanes 3 to 6). Although these bands were also detected in the samples of green regions and the samples of whole leaf (Fig. 2B,

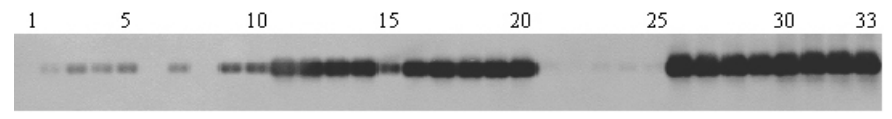

Fig. 1. Southern blot of reverse transcription-polymerase chain reaction (RTPCR) products of Potato virus A from extracts of potato plants grown at two temperatures. At 28 to $31^{\circ} \mathrm{C}$, 'Shepody' rootstocks (lanes 1 to 10 ), and 'Goldrus' scions at 90-days postgrafting (lanes 26 to 29). At 15 to $18^{\circ} \mathrm{C}$, 'Shepody' rootstocks (lanes 11 to 20), and 'Goldrus' scions at 90-days postgrafting (lanes 30 to 33 ); lanes 21 to 25 contain products from uninfected plants and PCR mix control. 
lanes 1 to 2 and 7 to 10 ), the intensity of the bands was much lower than that in the samples from chlorotic spots, indicating that the latter possessed a higher concentration of virus, whereas the green areas of chlorotic mosaic leaves had lower concentrations of PVA.

Association of necrosis in grafted 'Shepody' stems with PVA. To investigate possible causes of the discrete necrotic streaks in stems, RT-PCR-SB was carried out to investigate the occurrence of PVA in these samples, including stems of healthy grafted (rootstock/scion) 'Shepody' plants and visibly necrotic and nonnecrotic areas of stems of graft-inoculated 'Shepody' plants. Strong PVA bands were observed in the necrotic samples (Fig. 3, lanes 6 to 10), whereas fainter viral bands were present in the nonnecrotic samples (Fig. 3, lanes 11 to 15). No PVA-specific bands were observed in the healthy stem samples.

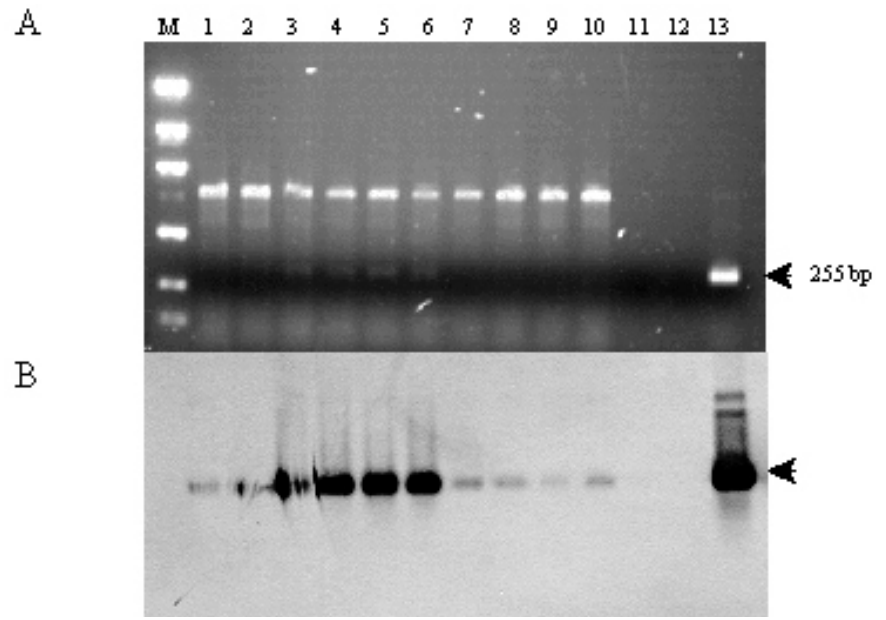

Fig. 2. Southern blot of reverse transcription-polymerase chain reaction (RTPCR) products from extracts of various parts of stems grafted to Potato virus A (PVA)-infected tissue 'Shepody' leaves. A, Analysis of RT-PCR products by agarose gel electrophoresis. Lane M, molecular size markers; lanes 1 and 2 , extracts from chlorotic mosaic whole leaf; lanes 3 to 6 , chlorotic areas from a chlorotic leaf; lanes 7 to 10 , green areas from the chlorotic leaf; lanes 11 and 12, negative uninfected control; and lane 13, purified virus A RNA control. Note only very faint bands at PVA position. The higher band is unknown nonspecific band. B, Southern blot of the gel shown in A. Arrow indicates the location of PVA fragment.
Because the virus appeared to be transported from the scion to various tissues including the leaves and stems, the occurrence of PVA in other tissues was investigated by RT-PCR-SB. Strong PVA bands were detected in the stolon (necrotic) samples (Fig. 3, lanes 20 to 23), and fainter bands appeared in the petiole (nonnecrotic) samples (Fig. 3, lanes 16 to 19). Although unevenly distributed in petioles and stolons, the presence of virus in these two key organs connecting the leaves and the tubers, respectively, indicates that the virus may be translocated to all parts of the plants.

Association of necrosis in tubers of grafted 'Shepody' plants with PVA. 'Shepody' rootstock grafted with PVA-infected scions produced tubers with various degrees of necrosis, ranging from surface necrosis to internal necrotic hard and dry tissues (30). To investigate the presence of PVA in these tissues, RT-PCR-SB was carried out on extracts of tubers from graft-inoculated 'Shepody' plants and also nonnecrotic tubers from susceptible 'Goldrus' plants. The tubers were sampled shortly after harvesting and after 3 months of storage at 20 to $25^{\circ} \mathrm{C}$.

Although PVA-specific bands were detected in samples from both necrotic (Fig. 4A, lanes 1 to 5) and nonnecrotic areas (Fig. $4 \mathrm{~A}$, lanes 6 to 10) of freshly harvested tubers of graft-inoculated 'Shepody' plants, the intensity of bands from the necrotic areas was markedly stronger than that from the nonnecrotic areas. PVA bands were present in samples of nonnecrotic tubers from susceptible 'Goldrus' plants (Fig. 4A, lanes 11 to 16). After 3-month storage of necrotic tubers at room temperature, PVA was detected only from necrotic areas (Fig. 4B, lanes 6 to 10) of tubers of graftinoculated 'Shepody' and from the whole nonnecrotic tubers of PVA susceptible 'Goldrus' (Fig. 4B, lanes 16 to 20). PVA was not detected in nonnecrotic areas of tubers of graft-inoculated 'Shepody' plants (Fig. 4B, lanes 11 to 15) or in tubers from healthy 'Shepody' plants (Fig. 4B, lanes 1 to 5).

Induction of PR genes by PVA in 'Shepody'. The relative expression of several PR genes was examined in different tissues of 'Shepody' plants and tubers. Samples included leaves and stems with chlorotic and necrotic symptoms from 10 graft-inoculated plants, 15 necrotic tubers collected from these plants and 10 leaves, stems, and tubers from plants grafted with healthy scions. The PR genes included were chitinase $\mathrm{A}$ and $\mathrm{B}$ (Cht $\mathrm{A}$ and $C h t \mathrm{~B})$, glucanase B (Glu B), PR-10a, and the coxl gene, which is not a $\mathrm{PR}$ gene but was used as control. Although differing in degree, all tested PR genes were induced by PVA in leaves, stems, and tubers of graft-inoculated 'Shepody' plants (Fig. 5A, lanes 1, 2, 5, and 7;

\section{Healthy plants Stem

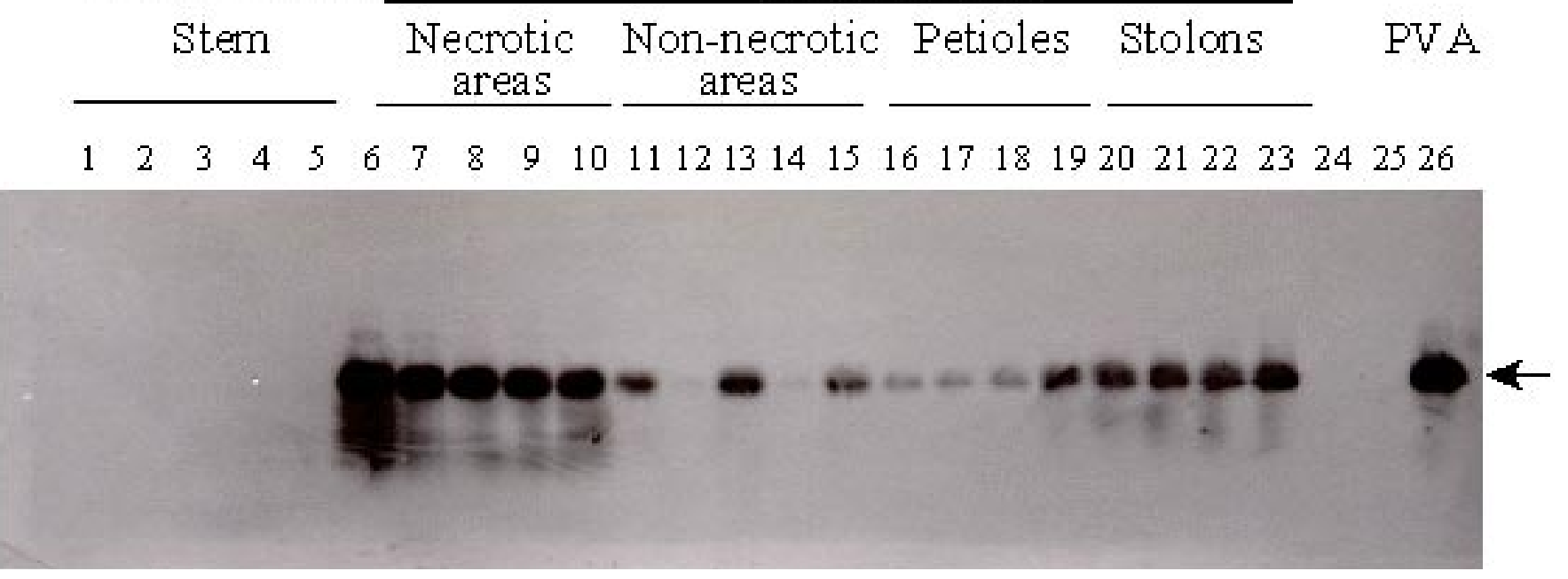

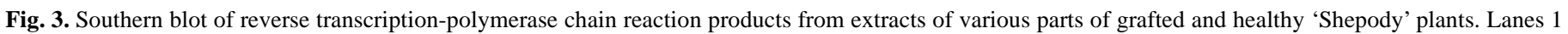

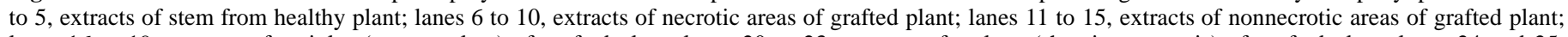

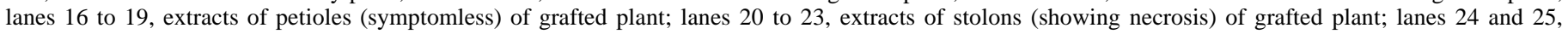
negative controls; and lane 26, purified Potato virus A (PVA) RNA. Arrow indicates the location of PVA fragment. 
Fig. 5B, lane 2). Detection of PVA-specific RNA was faint from the symptomless whole leaf (Fig. 5A, lane 1), stronger from whole leaf extracts showing chlorotic spot symptoms (Fig. 5A, lane 2), and strongest from the leaves of the infected scions (susceptible plants) (Fig. 5A, lane 3). The coxl gene was expressed at the same level in all leaf samples (Fig. 5A, coxl).

Expression of $C h t A$ and $C h t B$ did not vary significantly between whole symptomatic and symptomless leaves (Fig. 5A, lanes 1 to 2), chlorotic spots (lane 5), and green areas (lane 4). In contrast, Glu $B$ and $P R-10 a$ genes were expressed more strongly in symptomatic whole leaf (Fig. 5A, lane 2) than in symptomless whole leaf in graft-inoculated 'Shepody' (Fig. 5A, lane 1).

When chlorotic spots (Fig. 5A, lane 5) and green areas (Fig. $5 \mathrm{~A}$, lane 4) in symptomatic leaves were tested for PVA as well for $\mathrm{PR}$ gene expression, there was a close association between all PR gene expression and PVA accumulation in the chlorotic spots. Both PR-10a and Glu $B$ were induced to a greater level in chlorotic spot and green areas than $C h t A$ and $C h t B$ genes.

In stems, all the PR genes were expressed at much higher levels in necrotic areas (Fig. 5A, lane 7) than in the nonnecrotic areas (Fig. 5A, lane 6). Similarly, PVA concentration was higher in the necrotic areas than in the nonnecrotic areas (Fig. 5A, lanes 6 and 7), but coxl expression did not vary.

In tubers from graft-inoculated 'Shepody' plants, all four PR genes (Cht A, Cht B, Glu B, and PR-10a) were expressed more strongly in necrotic areas (Fig. 5B, lane 2) accompanied by enhanced accumulation of PVA (Fig. 5B, lane 2, PVA) than in nonnecrotic areas (Fig. 5B, lane 1, PVA). In contrast, although a strong PVA band was detected in susceptible 'Goldrus' tubers (Fig. 5B, lane 3, PVA), the PR gene expression remained at a relatively low level (Fig. 5B, lane 3). The level of expression of coxl was the same in all samples (Fig. 5B, coxl).

Association of lipid peroxidation with the necrosis response. To investigate the possible involvement of active oxygen species in PVA resistance in 'Shepody', lipid peroxidation was measured. Lipid peroxidation was highest in the necrotic areas of tubers and stems (Table 2), where PVA accumulation was greatest (Figs. 3 and 4).

Estimation of virus titer in necrotic streaks of tubers and stems. It appears that the development of necrosis in stems may be the result of a delayed or failing HR response in these tissues compared with the intensive necrosis observed in tubers, but both were directly associated with the presence of PVA. To determine the extent of variation in virus titer in these tissues, the PVA concentration in different tissues was estimated by a quantitative RTPCR with purified PVA RNA as a standard. After RT-PCR-SB analysis, virus concentration in the tissues was calculated from the scanned data in comparison with the standards. On the basis of three experiments and four replicates of each sample, PVA RNA concentration in stem tissue was estimated to be $10 \mathrm{pmol}$ in the necrotic areas and only 0.5 pmol in symptomless areas; similarly in the tubers, 26 pmol of RNA occurred in the necrotic areas and unquantifiable band intensity in nonnecrotic areas.

Absence of PVA in new plants from tubers of graft-inoculated 'Shepody' plants. After confirmation of the presence of PVA in the necrotic areas of graft-inoculated 'Shepody' plants by RT-PCR-SB, 38 tubers were planted in a greenhouse, with 15 tubers from healthy (nonnecrotic) 'Shepody' plants and 15 tubers from susceptible 'Goldrus' plants infected with PVA. The PVA bands were detected only in plants emerging from tubers of susceptible

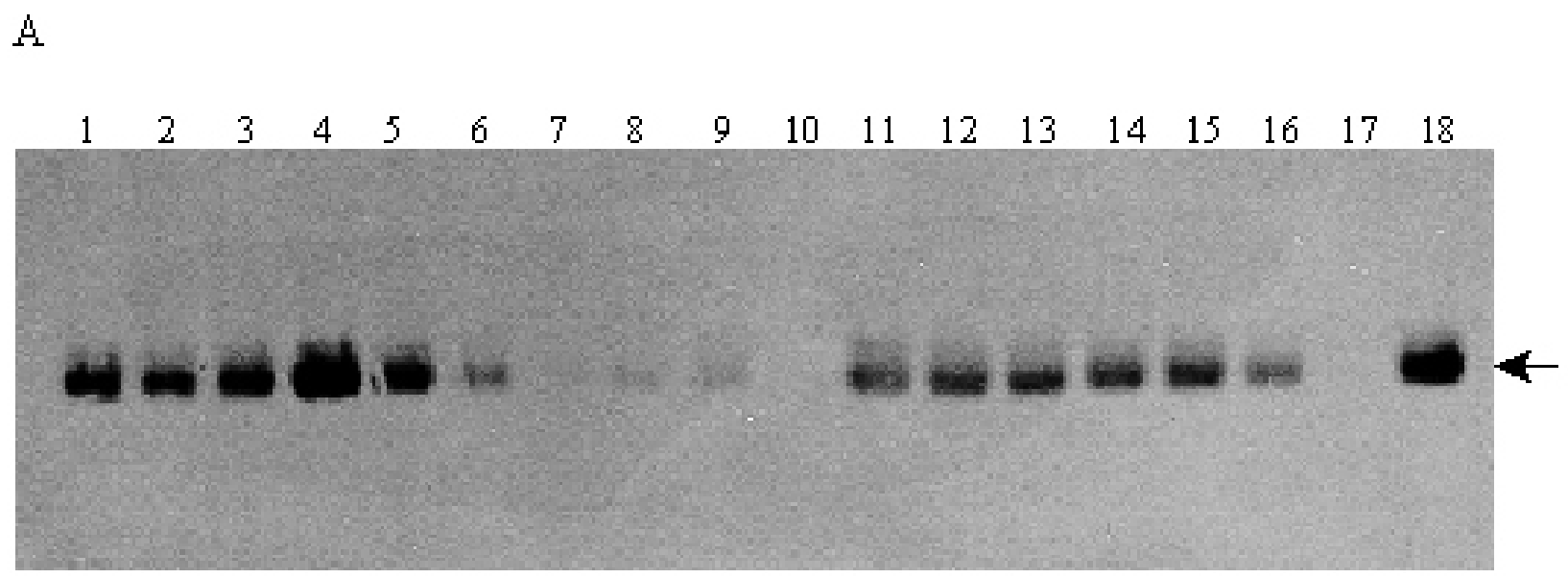

B

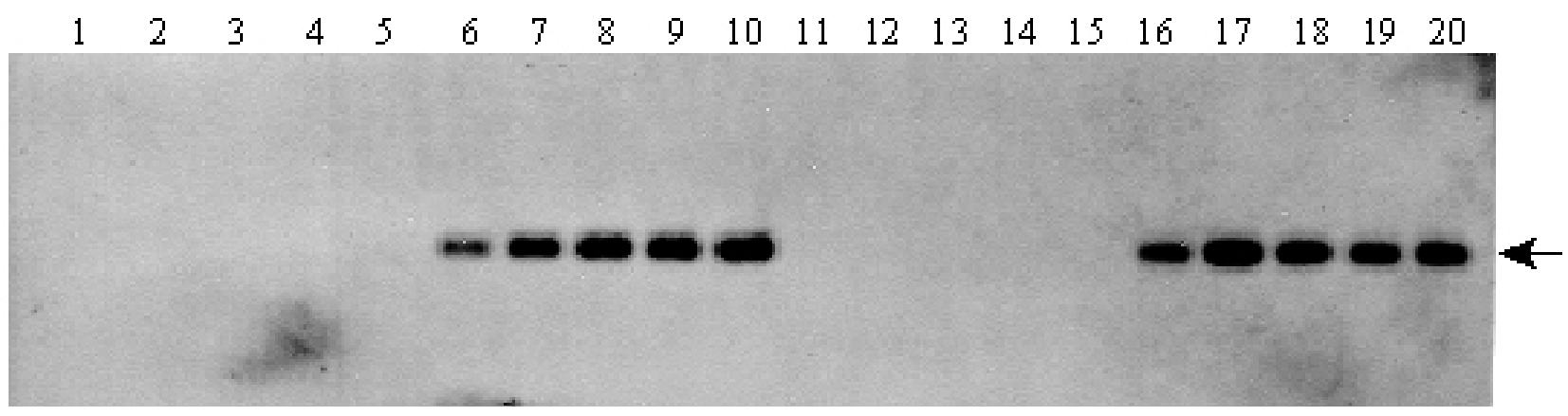

Fig. 4. Southern blot of reverse transcription-polymerase chain reaction products of tubers. A, Tissue extracted immediately after harvest: lanes 1 to 5 , necrotic tissue; lanes 6 to 10, nonnecrotic tissue; and lanes 11 to 16, nonsymptomatic tuber tissue from susceptible 'Goldrus'. Arrow indicates the location of Potato virus A (PVA) fragment. B, Tissue extracted after 3 months in storage. Lanes 1 to 5, healthy tuber tissue from symptomless tubers; lanes 6 to 10, PVA-infected necrotic tuber tissue; lanes 11 to 15 , nonnecrotic tuber tissue; and lanes 16 to 20, PVA-infected 'Goldrus' tuber tissue. 
plants. We tested sprouts from necrotic areas of graft-inoculated 'Shepody' tubers as they emerged and found 10 of 38, that originated at the border of necrotic and nonnecrotic areas, were positive for PVA. However, no PVA was detected in plants that grew from tubers of either grafted 'Shepody' or healthy 'Shepody' including the positive sprouts. This indicated that the second generation of PVA-grafted 'Shepody' plants were free from PVA. We considered the possibility that a trace amount of PVA may have existed in plants grown from tubers with necrotic symptoms. Therefore, RNA from leaves, stems, and new tubers at several developmental stages was tested in RT-PCR-SB. None were infected with PVA, confirming that the virus was lost during the storage and sprouting process.

\section{DISCUSSION}

In this study, temperature had a profound effect on the appearance of chlorotic and necrotic symptoms in PVA graft-inoculated 'Shepody' rootstock. The necrosis was greater at 15 rather than at $28^{\circ} \mathrm{C}$. PVA causes more necrotic local lesions at $15^{\circ} \mathrm{C}$ than at higher temperatures in indicator plant Physalis angulata (28), which indicates that lower temperatures are more favorable for PVA infection and replication. The $N$ gene-mediated HR has long served as the model for plant-pathogen systems. Because Samuel (26) demonstrated that TMV induced small local lesions in $N$. glutinosa at $21^{\circ} \mathrm{C}$, whereas larger local lesions at $28^{\circ} \mathrm{C}$ and no local lesions at $35^{\circ} \mathrm{C}$, temperature studies are used as a criterion of HR characterization. The temperature at which HR phenotypes are altered (i.e., local to systemic expression) differs in response to different TMV isolates (8) and TMV mutants (22), suggesting that temperature sensitivity of HR phenotypes in these instances
A

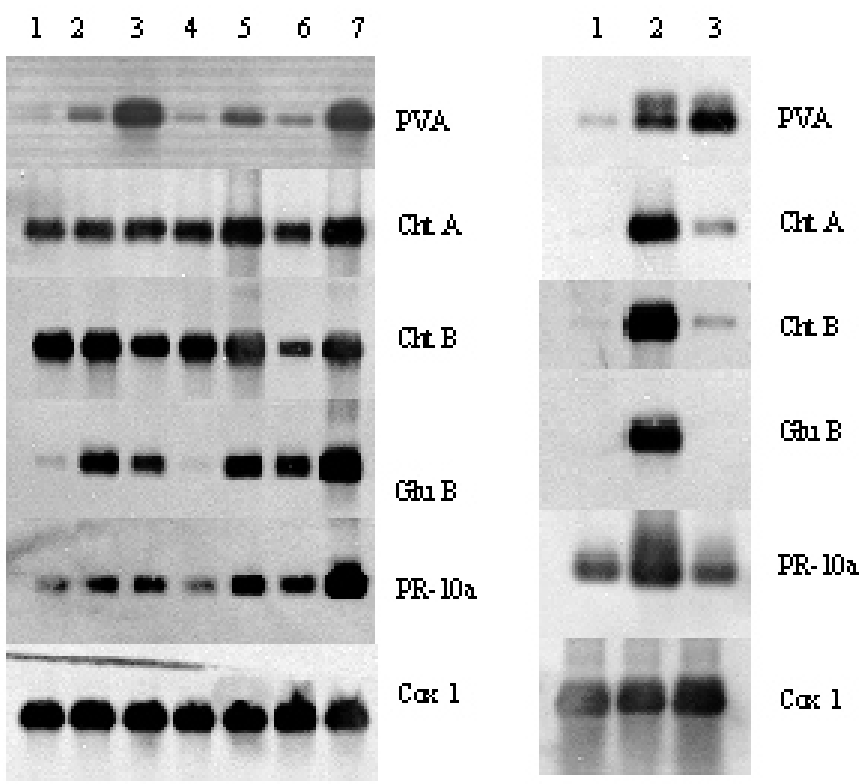

may not be a property of the host but a property of the virus (22). It is possible that our PVA strain activates the chlorotic and necrotic response in 'Shepody' at $15^{\circ} \mathrm{C}$. Altering growth temperature can modify movement and systemic accumulation pattern of viruses with minimal effects at the initial sites of infection $(9,11)$. Therefore, the precise temperature at which a HR fails to localize virus accumulation may differ among viruses and may be linked to the temperatures at which optimal viral replication occurs. It is also possible, however, that the lower temperature has affected the hosts response to virus.

It has been suggested that an interaction between elicitor molecule, generated by a pathogen gene, and a receptor, encoded by a resistance gene of the host plant, leads to the activation of a signal transduction cascade that eventually results in a HR (33). However, at present, the precise sequence of HR development is unknown. The recent isolation and cloning of $N$ and $R x$ genes from plants has shown that the appearance of a necrotic HR at the initial site of infection may not be a crucial effect of the genes that elicit HR expression. The $R x$-mediated ER against PVX in potato does not produce HR at the initial site of mechanical inoculation but does so in graft-inoculated plants (5). Despite this difference, the $R x$-gene product is structurally similar to the $N$-gene product, and it confers ER and has the potential to initiate cell death (5). The PVA-'Shepody' system has striking similarity to that of the $R x$-mediated resistance (5), in that 'Shepody' plants do not exhibit necrosis when rub-inoculated with PVA but do so upon graft inoculation when the plants are maintained at lower temperature. The lack of HR expression at the initial infection site may depend on virus concentration and translocation to certain "receptor" sites. In graft-inoculated plants, a continuous supply of virus from susceptible scions would result in its translocation through the resistant rootstock, as in $R x$-mediated resistance such that PVX translocation through the phloem of resistant plants is not suppressed (5). Therefore, once viral accumulation has reached an appropriate concentration and at a specific tissue site a HR-like response would be initiated. We have shown that the concentration of PVA observed in chlorotic leaves and necrotic stem and tuber tissues was consistently higher than that observed in nonsymptomatic plant parts (Fig. 2).

The PVA-'Shepody' system demonstrates the expression of PR genes and the generation of oxidative reactive species, which are typical of HR production in other plant-pathogen systems. However, it varies from the classical HR type of plant-virus interaction in its response to low temperatures and the absence of a localized necrotic response. In addition, 'Shepody' plants appear to mount an effective PVA restriction response in tubers. The tubers showing severe necrosis and detectable PVA yield second generation plants with no detectable PVA. This indicates virus movement, replication or both are arrested in some way during tuber storage and sprouting (Fig. 4). Virus arrest continues through the sprouting stage, because some sprouts originating at the junction of necrotic/nonnecrotic area contained PVA, but virus was not detected when the leaves from such plants were tested. The mechanism of virus loss in infected tuber/sprout is not known and further studies are needed.

The PVA-'Shepody' system shows features characteristic of a failed HR interaction. First, the accumulation of PVA in grafted

TABLE 2. Lipid peroxidation in tissues of 'Shepody' plants grafted with scions containing Potato virus A

Fig. 5. Southern blot of reverse transcription-polymerase chain reaction
products of various pathogenesis-related (PR) protein mRNAs from extracts representing $\mathbf{A}$, leaves and stems of grafted 'Shepody' and B, tuber. A, PR gene expression in leaves and stems. Whole leaf (lanes 1 to 3); symptomless leaf (lane 1); symptomatic leaf (lane 2); and leaf of scions containing virus (lane 3). Green areas (lane 4) and chlorotic spots (lane 5) of symptomatic leaf. Nonnecrotic areas (lane 6) and necrotic areas (lane 7) of stems of grafted plants. B, PR gene expression in tubers: nonnecrotic tissue (lane 1) and necrotic tissue (lane 2) of symptomatic tubers; and tuber tissue of Potato virus A (PVA)-infected susceptible 'Goldrus' (lane 3). Each gene is identified on the right side. a Absorbence per gram fresh weight.

\begin{tabular}{lc}
\hline Tissues & $\Delta A_{532-600}\left(A_{532} \mathrm{~g}^{-1} \mathrm{fwt}\right)^{\mathrm{a}}$ \\
\hline Nonnecrotic areas of stems & $0.400 \pm 0.032$ \\
Necrotic areas of stems & $0.886 \pm 0.118$ \\
Stolons (nonnecrotic) & $0.479 \pm 0.078$ \\
Nonnecrotic areas of tubers & $0.329 \pm 0.048$ \\
Necrotic areas of tubers & $0.680 \pm 0.048$ \\
\hline
\end{tabular}


'Shepody' plants is localized, but in discrete places distant from the inoculation site, and the virus fails to multiply in second generation plants grown from diseased necrotic tubers. Second, the increased expression of PR protein genes, characteristically associated with other HR (16), is induced in chlorotic or necrotic areas of the leaves, stems, and particularly the tubers of grafted 'Shepody' (Fig. 5). Third, the generation of oxidants was characteristic of PVA-'Shepody' interactions, where high concentrations of TBARs were observed in the necrotic areas that PVA accumulated (Table 2, Figs. 3 and 4).

We concluded that response of potato cv. Shepody to PVA shares many of the characteristics of HR-like responses demonstrated by viral, fungal, and bacterial pathogens $(14,22)$. The slow appearance of symptoms, low virus concentration, and induction of PR protein genes indicate that cv. Shepody is highly resistant to PVA. We propose that the continuous supply of virus from infected scions under experimental conditions forces the plant to react by the production of visible symptoms. Thus, it is a unique model system to elucidate the various steps of a systemic necrosis response in a vegetatively propagated crop.

\section{ACKNOWLEDGMENTS}

We thank K. Ready and A. Singh for editorial assistance; N. Pothier, A. Dilworth, and J. Zeng for technical assistance; E. Kombrink of MäxPlanck-Institut für Züchtungsforschung, Germany, for cDNA clones of chitinase A and B and glucanase B; and N. Brisson of Université de Montréal, Canada, for the PR-10a cDNA clone.

\section{LITERATURE CITED}

1. Bagnall, R. H. 1961. Hypersensitivity to virus $A$ and $X$ in Canadian and American potato varieties. Am. Potato J. 38:192-202.

2. Barker, H. 1996. Inheritance of resistance to potato virus $\mathrm{Y}$ and $\mathrm{A}$ in progeny obtained from potato cultivars containing gene Ry: Evidence for a new gene for extreme resistance to PVA. Theor. Appl. Genet. 93: 710-716.

3. Bartels, R. 1971. Potato virus A. No. 54 in: Descriptions of Plant Viruses. Commonw. Mycol. Inst./Assoc. Appl. Biol., Kew, England.

4. Bawden, F. C. 1936. The viruses causing top necrosis (acronecrosis) of potato. Ann. Appl. Biol. 23:487-497.

5. Bendahmane, A., Kanyuka, K., and Baulcombe, D. C. 1999. The $R x$ gene from potato controls separate virus resistance and cell death responses. Plant Cell 11:781-791.

6. Cockerham, G. 1943. The reactions of potato varieties to X, A, B, and C. Ann. Appl. Biol. 30:338-344.

7. Cockerham, G. 1970. Genetical studies on resistance to potato virus $\mathrm{X}$ and Y. Heredity 25:309-348.

8. Dijkstra, J., Bruin, G. C. A., Bergers, A. C., Loon, L. C., van Ritter, C., Sanden, P. A. C. M., and van de Wieringa-Brants, D. H. 1977. Systemic infection of some N-gene-carrying Nicotiana species and cultivars after inoculation with tobacco mosaic virus. Neth. J. Plant Pathol. 83:41-59.

9. Ding, X. S., Flasinski, S., and Nelson, R. S. 1999. Infection of barley by brome mosaic virus is restricted predominantly to cells in and associated with veins through a temperature-dependent mechanism. Mol. PlantMicrobe Interact. 12:615-623.

10. Doke, N., and Ohashi, Y. 1988. Involvement of an $\mathrm{O}_{2}$-generating system in the induction of necrotic lesions on tobacco leaves infected with tobacco mosaic virus. Physiol. Mol. Plant Pathol. 32:163-175.

11. Hamilton, R. I., and Nichols, C. 1977. The influence of bromegrass mosaic virus on the replication of tobacco mosaic virus in Hordeum vulgare. Phytopathology 67:484-489.

12. Hammond-Kosack, K. E., and Jones, J. D. G. 1997. Plant disease resistance genes. Annu. Rev. Plant Physiol. Plant Mol. Biol. 48:575-607.

13. Jones, R. A. C. 1990. Strain specific and virus specific hypersensitive reactions to infection with potyviruses in potato cultivars. Ann. Appl. Biol. 117:93-105.
14. Keen, N. T. 1992. The molecular biology of disease resistance. Plant Mol. Biol. 19:109-122.

15. Lamb, C., and Dixon, R. A. 1997. The oxidative burst in plant disease resistance. Ann. Rev. Plant Physiol. Plant Mol. Biol. 48:251-275.

16. Linthorst, H. J. M. 1991. Pathogenesis-related proteins of plants. Crit. Rev. Plant Sci. 10:123-150.

17. MacLachlan, D. S., Larson, R. H., and Walker, J. C. 1954. Potato virus A. Am. Potato J. 31:67-72.

18. May, J. M., Hammond-Kosack, K. E., and Jones, J. D. G. 1996. Involvement of reactive oxygen species, glutathione metabolism, and lipid peroxidation in the $C f$-gene-dependent defense response of tomato cotyledons induced by race-specific elicitors of Cladosporium fulvum. Plant Physiol. 110:1367-1379.

19. Mohapatra, S. S., Poole, R. J., and Dhindsa, R. S. 1987. Changes in protein patterns and translatable messenger RNA populations during cold acclimation of alfalfa. Plant Physiol. 84:1172-1176.

20. Munoz, F. J., Plaisted, R. L., and Thurston, H. D. 1975. Resistance to potato virus $\mathrm{Y}$ in Solanum tuberosum spp. Andigena. Am. Potato J. 52:107-115.

21. Nie, X., and Singh, R. P. 2000. Detection of multiple potato viruses using an oligo(dT) as a common cDNA primer in multiplex RT-PCR. J. Virol. Methods 86:179-185.

22. Padgett, H. S., Watanabe, Y., and Beachy, R. N. 1997. Identification of the TMV replicase sequence that activates the $N$ gene-mediated hypersensitive response. Mol. Plant-Microbe Interact. 10:709-715.

23. Petrunak, D. M., Gildow, F. E., and Christ, B. J. 1991. Incidence and distribution of six viruses infecting potatoes in Pennsylvania. Plant Dis. 75:644.

24. Rajamäki, M., Merits, A., Rabenstein, F., Andrejeva, J., Paulin, L., Kekarainen, T., Kreuze, J. F., Forster, R. L. S., and Valkonen, J. P. T. 1998. Biological, serological, and molecular differences among isolates of potato virus A potyvirus. Phytopathology 88:311-321.

25. Ross, H. 1986. Potato Breeding-Problems and Perspectives. Adv. Plant Breed. Suppl. 13. J. Breed. Springer-Verlag, Berlin.

26. Samuel, G. 1931. Some experiments on inoculating methods with plant viruses, and local lesions. Ann. Appl. Biol. 18:494-507.

27. Shukla, D. D., Ward, C. W., and Brunt, A. 1994. The Potyviridae. CAB International, Wallingford, U.K

28. Singh, R. P. 1982. Physalis angulata as a local lesion host for postharvest indexing of potato virus A. Plant Dis. 66:1051-1052.

29. Singh, R. P. 1997. High levels of potato virus A resistance in cultivars Bake King and Shepody. (Abstr.) Am. Potato J. 74:467.

30. Singh, R. P., Nie, X., and Tai, G. C. C. 2000. A novel hypersensitive resistance response against potato virus A in cultivar 'Shepody'. Theor. Appl. Genet. 100:401-408.

31. Singh, R. P., and Singh, M. 1998. Specific detection of potato virus A in dormant tubers by reverse transcription polymerase chain reaction. Plant Dis. 82:230-234

32. Singh, R. P., and Smith, E. M. 1977. Predominance of potato virus A in 'mosaic complex' of Netted Gem potatoes. (Abstr.) Am. Potato J. 54:477.

33. Staskawicz, B. J., Ausubel, F. M., Baker, B. J., Ellis, J. G., and Jones, J. D. G. 1995. Molecular genetics of plant disease resistance. Science 268:661-667.

34. Swiezynski, K. M. 1994. Inheritance of resistance to viruses. Pages 339363 in: Potato Genetics. J. F. Bradshaw and G. R. Mackay, eds. CAB International, Wallingford, U.K.

35. Valkonen, J. P. T. 1994. Genes and mechanisms for resistance to viruses in cultivated and wild potato species (Solanum spp.). Plant Breed. 112: $1-16$.

36. Valkonen, J. P. T., Jones, R. A. C., Slack, S. A., and Watanabe, K. N. 1996. Resistance specificities to viruses in potato: Standardization of nomenclature. Plant Breed. 115:433-438.

37. Valkonen, J. P. T., Puurand, U., Slack, S. A., Mäkinen, K., and Saarma, M. 1995. Three strain groups of potato A potyvirus based on hypersensitive responses in potato, serological properties, and coat protein sequences. Plant Dis. 79:748-753.

38. Webb, R. E., and Schultz, E. S. 1959. The evaluation of potato seedling varieties for field immunity from potato virus A. Am. Potato J. 36:275283.

39. Whitham, S., Dinesh-Kummar, S. P., Choi, D., Hehl, R., Corr, C., and Baker, B. 1994. The product of the tobacco mosaic virus resistance gene $N$ : Similarity to Toll and the interleukin-1 receptor. Cell 78:1011-1015. 